\title{
IMPROVING ENGLISH SPEAKING SKILLS IN DAILY CONVERSION FOR YOUTH IN THE TEMPE DISTRICT
}

\author{
Satriani ${ }^{1^{*}}$ \\ Muhammad Hasbi ${ }^{2}$ \\ 1,2 Institut Agama Islam As'adiyah Sengkang, Sengkang, Indonesia \\ satrianiani200894@gmail.com ${ }^{\left.{ }^{*}\right)}$ \\ $\underline{\text { muhammad.hasbi80@gmail.com }}^{2)}$
}

Keywords: [Tourism, Youth, English Language Skills]

Published by:

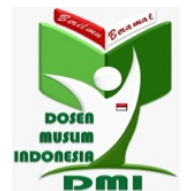

Copyright (C) 2021 The Author(s)

This article is licensed under CC BY 4.0 License (cc) BY

https://dmi-journals.org/jai
Abstract: The Wajo Regency administration is currently concerned about the development of tourism attractions; tourist attractions are being refurbished and renovated in order to attract tourists from within and beyond the Regency, as well as the local government expecting tourists. tourism enhancement program must be complemented by an increase in human resources, particularly in the field of English, because regional advancement continues to increase, as evidenced by improvements in the city of Sengkang in terms of better structuring specific tourist sites. Human resource development can take the form of English classes in addition to building a responsible workforce and developing regional potential (becoming a tourist guide), as well as encouraging adolescents to participate actively in government tourism programs. 


\section{Introduction}

The tourism sector in Kab. Wajo is getting better organized, so it has attracted local and foreign tourists to visit these places, such as: Tempe Lake Tours, etc.

The development of tourist attractions in Wajo Regency must also be accompanied by an increase in human resources, especially in the field of English. Currently, English is still the main language of instruction in the world, so it is still said to be an international language. It is undeniable that the learning of English obtained in junior high and high school has not guaranteed its output, especially among the youth who can speak English well. Therefore, to help improve the English skills of the youth in Wajo Regency, in this case, in Tempe District, a workshop on improving English speaking skills was held, which was carried out by the community service team of IAI lecturer As'Adiyah. The English proficiency in question is the ability to speak English in the form of daily conversations related to tour guides. Implementation of activities is in the form of courses. It is intended that after completing this course, the knowledge gained can be immediately applied to real-life situations encountered in the field.

Thus, community service, namely improving the ability to speak English in daily conversation for youths in Wajo Regency, Tempe District, is truly an activity that has positive synergy and is beneficial for local governments and, in particular, for young people.

\section{Implementation Method}

\section{Preparation and Debriefing}

The mechanism for implementing community service activities includes:

1. Preparation

2. Field observation

3. Workshop location selection

4. Workshop registration

5. Students and field supervisors (DPL) debriefing

6. Monitoring evaluation

\section{Implemntation}

The Community Service Program with the title "Improving English Speaking Ability in Daily Conversation for Young People in Kec., Tempe, and Wajo Regency" is implemented by prioritizing the principle of empowering local communities with the main objectives of program sustainability and community independence. This program is carried out by means of socialization and training in every activity carried out.

The entire volume of student work participating in the community service workshop includes three (3) core activities, namely the implementation of English courses at the youth and community levels, the first additional activity of implementing English courses at the elementary level, and other supporting activities, including: a) the numbering of residents' houses, including designing and constructing hamlet boundaries of iron material as well as fixing them on the hamlet boundaries; c) establishing an Al- 
Qur'an Recitation Park (TPA) and involving themselves in its activities; and d) carrying out arts and sports activities with the community.

Specifically, the way of implementing the course is based on several things, namely the form of application of language teaching, which is based on the idea that (Breen et al., 2001; Basturkmen et al., 2004; Izzan, 2010; Block et al., 2012; Richards \& Schmidt, 2013; Manara, 2018; Poole, 2020) "the teacher who teaches his class is actually involved in applied linguistics." To apply language materials, Nurhadi \& Senduk (2004); Lestari \& As'ari (2013); Octavita \& Saraswati (2017); Fu et al. (2019); Usman et al. (2019); Lin et al. (2020); Manabe et al. (2021); Al Hilali \& McKinley (2021) suggests that learning should be done contextually, namely "placing students in a meaningful context that connects students' prior knowledge with the material being studied and, at the same time, pays attention to the individual needs of students and the role of the teacher." Giving courses in the district Nurhadi's thoughts are based on Nurhadi's thoughts on Tempe and the goal of improving speaking skills in English. Furthermore, Nurhadi \& Senduk (2004), on the same page, emphasizes several important things in contextual learning, such as: 1) problem-based learning, 2) authentic teaching, 3) inquiry-based learning, 4) projectbased learning, 5) work-based learning, 6) service-based learning and services, and 7) cooperative-based learning.

According to McCafferty (2006); Jolliffe (2007); Slavin (2013); Richards \& Rodgers (2014); Rosita \& Leonard (2015); Angriani et al. (2016); Muñoz-Martínez et al. (2020); Major (2020), the purpose of cooperative learning is to make maximum use of cooperative activities involving pairs and small groups of learners in the classroom.

In principle, the delivery of course materials to community members is correlated with two problems, namely: 1) language materials and 2) youth or students receiving English materials themselves. According to Ortega (2018); Bouchard (2021), "Teachers have faced the same dilemma that has worried the linguist: if they concentrate too hard on linguistic forms and forget the people who use the forms in ordinary communication, they distort the reality of language use." Furthermore, if their teachers emphasize the existence of community and territory and pay less attention to language forms in detail, their teaching becomes shallow and unusable.

Stern's opinion has its truth, but both of these are considered by a teacher or instructor and a course provider by paying attention to contextual learning as suggested by Nurhadi and other experts who support the best way of teaching in the classroom.

\section{Results and Discussion}

\section{Results of the Community Service Workshop Implementation in the Tempe District}

The implementation of the Service Workshop in the Tempe District according to what is in the field includes 3 main points: 1) the core activities of implementing English courses at the youth and citizen level, 2) the implementation of English courses at the elementary level, and 3) other supporting activities. The English language course activities were officially opened by the Chair and members of the advisory team on Monday, January 27, 2020. The course starts on Tuesday, January 27, 2020. Each of these activities is as follows:

1. The English course for youth and citizens was held on January 27, 2020, with a material introduction: February 2, 2020 with material on Part of the Body, 
February 2, 2020 with material on days, months, and years, February 3, 2020 with material on nouns, 03 February 2020 with noun material (Games: Guess What! ), 04 February 2020 with animal content, 04 February 2020 with Ordinal Numbers (Games Boom) material, 04 February 2020 with porfesion material 04 February 2020, 05 February 2020 with Days of the Week \& Moths of the Material Year, 6 February 2020 with Telling Time material, and 6 February 2020 with Simple Present Tense material.

2. 2. Other supporting activities carried out by participants at the location included: a) numbering of residents' houses from October 26, 2015 to February 3, 2020, including designing numbers and registering residents' houses; and b) designing and making hamlet boundaries from iron and fixing them to the hamlet boundaries from February 4, 2020 to February 4, 2020.c) Establishing an Al-Qur'an Recitation Park (TPA) and engaging in activities from February 5, 2020 to February 11, 2020; d) Carrying out arts and sports activities with the community from February 11, 2020 to February 15, 2020.

\section{The Core Activities of Implementing English Courses at the Youth and Citizen Level}

On Tuesday night, January 27, 2020, participants on behalf of Mujahidin, Basri, Dendi, and Akmal gave a course with a special material: Introduction. When delivering the material, they use the grammar translation method, the role-play technique, and the paper game. The media used are whiteboards, markers, printed books, and the internet. The Paper Game is a game that uses paper as a material to make small balls, after which the balls made of paper are given from one student to another, accompanied by an English song entitled Alphabet. This method is used so that course participants can more easily memorize the alphabet they are currently learning. While playing this game, they receive rewards according to who hits the ball and when the song stops. The reward is to introduce himself in English. This method is carried out to attract the interest of the 20 course participants. Based on the games that we provide, we can conclude that there are five people who have very good abilities, ten people who have average abilities, and five people who have low abilities.

On Monday, February 3, 2020, the lecturer, on behalf of Hasbi, gave a course with a special material: nouns. The methods used are Grammar Translation and the Whisper Game technique, which is a game that uses the sense of hearing as the main tool in playing this game. Participants were divided into 3 groups and given 1 English sentence as a keyword related to the material taught by the teacher. After being given the keyword, the three participants are ready to act. This method was carried out to attract the interest of the 19 course participants. Based on the given game, there are five people who have very good abilities, nine people who have average abilities, and five people who have low abilities.

On Wednesday, February 4 2020, the course was held with the same instructors. The material taught at this meeting is "Animal." At this meeting, the course participants were introduced to the names of the animals around them in English. The method used in learning is called the "lecture method." The instructor gave the game "Whispering" as a distraction in the learning process. The number of course participants at this meeting was 13 people. There are 3 course participants who are in the "very good" category. While those in the medium/average category are 8 , and those in the low/low category are 2 , 
The "excellent" category consists of course participants who are able to name the animals around them correctly and with the correct pronunciation. Meanwhile, the course participants were able to correctly name the animals around them but were not able to pronounce them correctly and were in the medium/average category. In the category of "less" or "low," there are those who have not been able to memorize the names of animals correctly.

This meeting uses the lecture method because this method is considered capable of presenting a wide range of subject matter because here it only relies on the voice of the teacher who focuses on the subject matter that leads directly to the animals that are around. But this method has a weakness because it is considered a boring method when the teacher is not able to communicate well. Therefore, it should be Teachers/instructors must have good communication skills so that the lecture method is not considered a boring method.

\section{Conclusions}

The findings of the community service workshop that lasted for several days in the Tempe District, Wajo Regency, showed the following results: The core activity of implementing the English course in daily conversation took place four times. The instructors in the course activities are both lecturers and students, and there are five groups of four members each. The results obtained by the participants from the English language material were dominated by average abilities in the medium category in mastering English in everyday conversation.

The findings of the course assessment by students and lecturers are carried out with a qualitative assessment, namely in 3 categories: good, medium, and low categories. The condition of the participants became very enthusiastic about English, both for youth groups and community members (general groups) because the course implementation by the community service team was directed in the form of intensive courses, considering that the workshop program only lasted a few days at the location.

\section{Refereces}

Al Hilali, T. S., \& McKinley, J. (2021). Exploring the socio-contextual nature of workplace writing: Towards preparing learners for the complexities of English L2 writing in the workplace. English for Specific Purposes, 63, 86-97.

Angriani, A. D., Bernard, B., Nur, R., \& Nurjawahirah, N. (2016). Meningkatkan Kemampuan Pemecahan Masalah Melalui Pembelajaran Kooperatif Think-TalkWrite Pada Peserta Didik Kelas Viii1 Mtsn Model Makassar. MaPan: Jurnal Matematika Dan Pembelajaran, 4(1), 11-28.

Basturkmen, H., Loewen, S., \& Ellis, R. (2004). Teachers' stated beliefs about incidental focus on form and their classroom practices. Applied linguistics, 25(2), 243-272.

Block, D., Gray, J., \& Holborow, M. (2012). Neoliberalism and applied linguistics (pp. 1-13). London: Routledge.

Bouchard, J. (2021). The Need for a Renewed Applied Linguistics. In Complexity, Emergence, and Causality in Applied Linguistics (pp. 27-93). Palgrave Macmillan, Cham. 
Breen, M. P., Hird, B., Milton, M., Oliver, R., \& Thwaite, A. (2001). Making sense of language teaching: Teachers' principles and classroom practices. Applied linguistics, 22(4), 470-501.

Fu, Q. K., Lin, C. J., Hwang, G. J., \& Zhang, L. (2019). Impacts of a mind mapping-based contextual gaming approach on EFL students' writing performance, learning perceptions and generative uses in an English course. Computers \& Education, 137, 59-77.

Izzan, A. (2010). Metodologi Pembelajaran Bahasa Inggris. Humaniora.

Jolliffe, W. (2007). Cooperative learning in the classroom: Putting it into practice. Sage.

Lestari, E., \& As'ari, A. R. (2013). Pengembangan modul pembelajaran soal cerita matematika kontekstual berbahasa Inggris untuk siswa kelas X. Malang: Universitas Negeri Malang.

Lin, C. J., Hwang, G. J., Fu, Q. K., \& Cao, Y. H. (2020). Facilitating EFL students' English grammar learning performance and behaviors: A contextual gaming approach. Computers \& Education, 152, 103876.

Major, C. (2020). Collaborative Learning: A Tried and True Active Learning Method for the College Classroom. New Directions for Teaching and Learning, 2020(164), 19-28.

Manara, C. (2018). DARI REFLEKSI PENGAJARAN HINGGA RANCANGAN PENELITIAN TINDAKAN KELAS (PTK): KEGIATAN LOKAKARYA BAGI PARA GURU BAHASA INGGRIS DI PROVINSI BANTEN. Jurnal Pengabdian Masyarakat Ilmu Keguruan dan Pendidikan (JPM-IKP), 1(02).

Manabe, K., Hwang, W. Y., \& Chuang, Y. W. (2021). English learning enhanced by collaborative contextual drama in an authentic context. Interactive Learning Environments, 1-17.

McCafferty, S. G. (Ed.). (2006). Cooperative learning and second language teaching. Cambridge University Press.

Muñoz-Martínez, Y., Monge-López, C., \& Torrego Seijo, J. C. (2020). Teacher education in cooperative learning and its influence on inclusive education. Improving Schools, 23(3), 277-290.

Nurhadi, B. Y., \& Senduk, A. G. (2004). Pembelajaran kontekstual dan penerapannya dalam KBK. Malang: Universitas Negeri Malang Pres.

Poole, R. (2020). "Corpus can be tricky": revisiting teacher attitudes towards corpusaided language learning and teaching. Computer Assisted Language Learning, 1-22.

Octavita, R. A. I., \& Saraswati, R. (2017). Integrasi Pendidikan Berkarakter Dalam Pembelajaran Bahasa Inggris. Jurnal Terapan Abdimas, 2, 33-40.

Ortega, L. (2018). Ontologies of language, second language acquisition, and world Englishes. World Englishes, 37(1), 64-79.

Richards, J. C., \& Schmidt, R. W. (2013). Longman dictionary of language teaching and applied linguistics. Routledge. 
Richards, J. C., \& Rodgers, T. S. (2014). Approaches and methods in language teaching. Cambridge university press.

Rosita, I., \& Leonard, L. (2015). Meningkatkan kerja sama siswa melalui pembelajaran kooperatif tipe Think Pair Share. Formatif: Jurnal Ilmiah Pendidikan MIPA, 3(1).

Slavin, R. E. (2013). Cooperative learning and student achievement. In School and classroom organization (pp. 129-158). Routledge.

Usman, H., Utami, N. C. M., \& Fajarianto, O. (2019). Model Bahan Ajar Bahasa Inggris Untuk SD Berbasis Pendekatan Kontekstual.JTP-Jurnal Teknologi Pendidikan, 21(3), 231240. 